\title{
Understanding Domestic Violence in Indonesia Through a Play-with-music: A Story of Wounds
}

\author{
Meilinda \\ Petra Christian University, INDONESIA \\ e-mail: meilinda@petra.ac.id
}

\begin{abstract}
The number of domestic violence is $50 \%$ out of violence against woman cases in Indonesia. It is intriguing and there must be a reason behind that. One of the ways that can be used to reflect on this subject is through theater, an art form that can discuss and inspire a necessary social change or agenda. Therefore, applying textual analysis method on A Story of Wounds, a playwith-music by Jessie Monika, I would like to find the core problem of domestic violence as portrayed there. I utilize Bourdieu's capital, habitus, and field theory to prove that inequality between the wife and the husband is caused by the deeply rooted patriarchy values which create power imbalance that opens the opportunity for domestic violence toward women and perceive the act more as a logical consequence of a marital relationship instead of a crime. The power imbalance is, however, not a permanent state and can be altered by the people around the victim and, in turn, the victim herself.
\end{abstract}

Keywords: Theater; domestic violence; habitus; capital; arena; patriarchy.

\section{INTRODUCTION}

In Indonesia, news related to domestic violence can easily be searched through online news portals. Liputan 6, Suara.com, Detik.com have a special page that groups news related to domestic violence. It is either a good sign or a bad one; that people now realize that domestic violence is a crime and be more open about it, or the media is more open covering and exposing domestic violence cases, or number of cases rise significantly than before. Domestic violence becomes part of the family picture in Indonesia. Based on Indonesia National Commission on Violence against Women report on March $5^{\text {th }}, 2021$, there were 3,321 violence cases towards women and statistically, $50 \%$ of it were domestic violence (Komnas Perempuan, 2021). The number of percentages is high, and it might be an indication of malfunction relations in the marriage institution or imbalanced power relation in marriage in Indonesia. Therefore, I am triggered to focus on this issue in this article. Research found that domestic violence is generally done by a dominant person with the closest relationship to the victim, and in the Indonesian context, a husband or life partner is a potential perpetrator of domestic violence (Syawitri \& Afdal, 2020). The forms of domestic violence in Indonesia included wife trafficking, physical abuse that caused death, and also psychological abuse that can happen verbally on day to day basis (Fitriyani, 2018).
Gadis Arivia, an expert in gender studies stated that domestic violence is a criminal act that is difficult to uncover because it is personal and other people are reluctant to interfere (2006). In line with what she stated, more efforts are needed to uncover these crimes because they occurred in the private sphere. Both perpetrators and victims can view this as a domestic affair and thus it is taboo for outsiders to interfere. As a result, there is a pressure of shame culture, that is, it is inappropriate for other people to know about domestic violence happening in a marriage and it stops the victim from telling others about the abuse/crime she has experienced. This makes domestic violence not only affect the victim's physical condition, but also mental conditions such as self-confidence and security (Syawitri \& Afdal, 2020). Thus, it is possible that the reported cases are only the tip of the visible iceberg.

Studies based on second wave feminism position and communicate women as victims in viewing these criminal events (Sulistyani, 2012). Women are put in a position of helplessness. This perspective can have an impact on the weakening of women's perception of their position and can affect their mindset, that women are indeed powerless. Meanwhile, third wave feminism sees women as parties who have the power to be an agent, to fight against the rules that constrain them and take control of their lives. Although critics say that another impact of third wave feminism is the commodification of women, women have more opportunities 
to take control of themselves (Hains, 2009). These two views approach the position of women in a binary opposition sense. I argue that domestic violence and the position of women in life and in domestic sphere to be more specific, is more complex. Power imbalance in domestic sphere as the result of patriarchal hegemony causes men's domination toward women and thus, enabling verbal and physical abuses. One of the solutions to solve this problem is through education.

An education to create a habitus that can accept equality between men and women is the key to stop domestic violence, and one of the forms of education is through theater. As stated by McKenna (2014), theater is a work of art that can be used to discuss and inspire a necessary social change or social agenda. Petra Little Theatre (PLT) is one of the campus theaters which, since 2013, has written and produced original productions (New Play Development, 2013). Although the script uses English as it is under English Department at Petra Christian University, the themes and issues are about various social conditions that need to be highlighted and challenge the status quo in Indonesia. The theater's ability to discuss and put a performance into the realm of imaginative narrative opens a space for creativity to be used. A critical attitude is aroused to seek answers and possibilities in seeing and addressing this issue. The presuppositional conditions offered by the theater can also create a sense of security to dissect this topic of domestic violence although there are also those who see that art can only offer discourse. However, I believe that the art world can raise the social awareness among art workers and the public and form a cultural agency for those involved, including the audience (Lally, E., Ang, I., and Anderson, 2011).

PLT's play-with-music entitled A Story of Wounds (ASoW) by Jessie Monika is one of the examples where a theater performance can be used as a tool to bring individual experiences into the public sphere as one of the collective memories related to crimes within domestic violence (Pamungkas, 2018). ASoW is written based on the story of a domestic violence survivor. Therefore, I borrowed ASoW to analyse the causes of domestic violence and uncover the schemata that influence this crime. In one of the interviews, Jessie Monika appealed to those who experienced it not to be silent, because "humans do not deserve to be treated like that" (Pamungkas, 2018). Through ASoW, the production team and audience had a chance to know and understand the existence of domestic violence which then triggered some of them to be the agent of change. The team consisted of 40 young people aged 19-23 years old. Borrowing Bloom's revised taxonomic theory, involvement in a production where a team produces a creative work is the most effective way of understanding a topic (Anderson et al., 2001) because in it is a process of understanding, planning, and producing something that resulted from the crystallization of that understanding. In line with Jessie Monika, Emily Abigail, who played the character Nina, revealed in her article in Jawa Pos that it is the inability of women to speak up and the inability of their environment to listen that can kill (Abigail, 2018). The entire production team was required to do personal research according to the role they played. Their involvement in this production opened their horizons for the existence of this problem as well as its causes and implications. The two male actors involved in this performance expressed the same thing in a discussion at the end of the production saying that joining this production made them see how domestic violence can damage women and how lucky they were to participate in this production before they got married. They became aware that they must listen and help when someone needs help. For female production members, they understood that if they seek help, there will be someone who helps. When this team of young people tried to present a performance, they also learned about and debated on the topics being discussed.

PLT produced ASoW at three different locations and time and received interesting comments from the audience. ASoW was performed at Petra Christian University - Surabaya in 2018 and 2019 and at Sanata Dharma University - Yogyakarta also in 2019. This production gathered attention and support from many including the National Commission on Violence against Women (Picture 1).

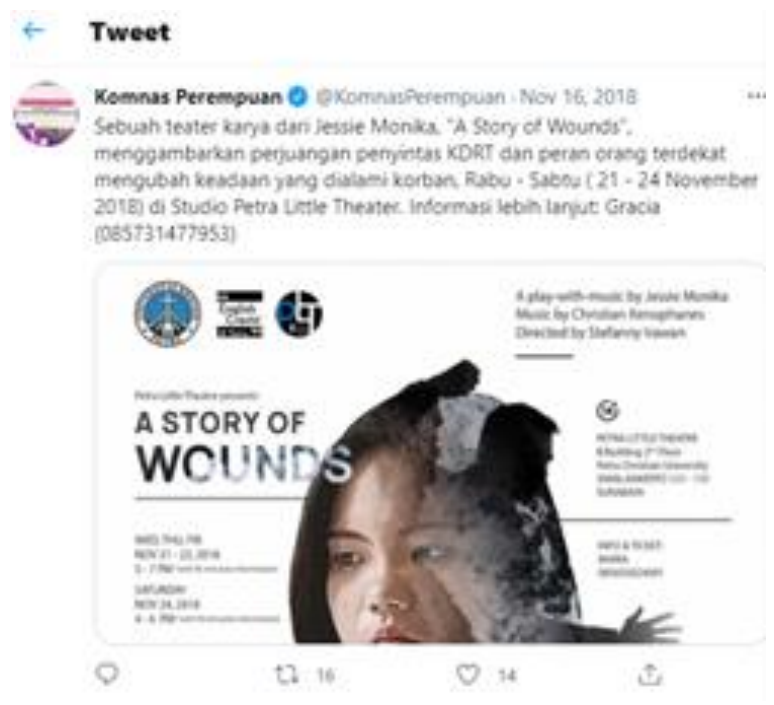

Picture 1. Publication of ASoW by the National Commission on Violence against Women on Twitter.

From the audience's perspective, ASoW opens a forum for this topic to be discussed and ponder upon. This 
production does use several forms for this matter: audio (music and words spoken by actors), visual (movements and gestures), and written (program books and social media posts). Indeed, ASoW theater performances cannot solve the problem, yet it can be a trigger for a reflection, a debate that leads to awareness about domestic violence and its effects.
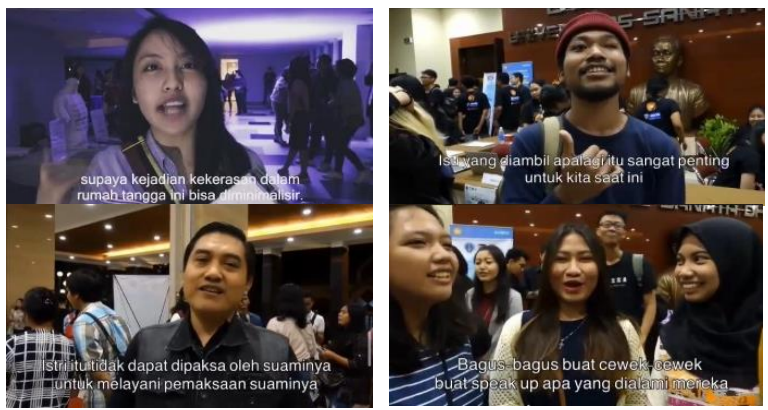

Picture 2. Screenshots from PLT' Instagram account displaying audience opinion about ASoW.

Staging is a visual medium that can be used because amid the excitement of the audience watching the show, without realizing it, sympathy for the main character and self-identification in the story can arise and trigger thoughts and actions. There are strengthened understandings, appeals, opinions and even hopes expressed by the audience regarding the real social conditions in Indonesia concerning domestic violence (Picture 2). Art then does carry out its social function.

ASoW is set in the upper middle class Christian families with Nina as the main character. The audience follows Nina's journey and her struggle to find a way out from her violent and malfunctioned marriage. Since her father fell sick, Nina's family has received help from Ruben, who works in Nina's father's company. Thinking about Nina's future, her mother forces Nina to marry Ruben. Ruben comes from a devout and respected Christian family. Living with her in-laws, Nina continues to work as a painter. Nina and Ruben decided not to have children first, but this stance was not in line with Ruben's parents'. The family, through his mother, repeatedly reminds Ruben that he is the head of the family and should control his wife. Ruben fails to handle the pressure, drowns himself in alcohol, and creates a new pattern of marriage life: a pattern of abuse (Picture3). He becomes an abusive husband, verbally and physically, to show his family that he has power over his wife. Nina, who is desperate and loses herself, then finds help from her model and brother-in-law. Through her paintings, Nina reveals the crimes committed by her husband and finally dares to save herself from a hellish marriage.

This article analyses the inequality in Ruben and Nina's marriage in connection with the capital and habitus they have, and the field created in the story. I found in my preliminary study that inequality is the cause of domestic abuse as portrayed in the marriage of the two main characters. Thus, I would like to find the reasons behind that inequality to find the core problem of domestic violence as portrayed in ASoW. The perspective that I use in analyzing this topic is constructivism. Behaviors produced by the main characters are constructed by the cultural setting where they are living in. Cultural approach will be used to build my argument regarding the topic. One of the important icons in Cultural Studies is Pierre Bordeau, a philosopher and sociologist from France, one of whose popular achievements is creating a theory of practice in social context (Harker et al., 1990). He focuses his work to regularities in the society to analyze it empirically so that it can be understood. Bourdeau believes that the position of an individual in the social space is not based on the class but based on the capital; the social space then becomes a field of capital. Therefore the key concept coming from Bourdeau are habitus and field in relation to capitals (Bourdieu, 2013; Harker et al., 1990; Wuriyani, 2020). Habitus is also used in several studies related to women's position in the society either in arts, politics related to diplomacy, and health to understand gender relation in structured culture, the practices, and the codes (Cohn, 2020; Doblyte, 2020; Standfield, 2020).



Picture 3. Nina (left) tried to calm Ruben (right) down in ASoW.

Habitus and field intertwine with the concept of capital. Capital is a weapon of domination used by the oppressor. In his concept, Bourdeau categorizes capital into social, cultural, and economic capital. To help me analyze ASoW and answer the research question that I have in this article, I will borrow Bordeau's capital, habitus, and field concepts. These concepts helped me understand both Ruben and Nina, and the nature of relation in the ecosystem where they live in that makes way for domestic violence to happen in their marriage.

\section{METHODOLOGY}

I applied textual analysis method, that is, under interpretative culture in the qualitative research, to examine ASoW in this article. This popular method 
enables me to dive beyond the text to find the underlying "ideology and cultural assumption" of the research subject (Arya, 2020). Textual analysis started in the late 1970s in the communication field, yet this technique has become popular not only in Social Sciences but also in Humanities and other fields (Arya, 2020; McKee, 2003; Smith, 2017). By utilizing the method, I had the opportunity to gather possible information and read possible interpretations that a text can offer.

Text in this context is not only the written text but it is "something that we make meaning from" (McKee, 2003). Text may take many forms such as a drama, a performance, a picture, a habit; things that can be observed and give opportunities to the researcher to draw a meaning out of them. In my article, the text that I use is a combination of the drama (written words), and the performance (spoken dialogues and gestures). The reason for this was to include gestures of the actors that sometimes can deliver different or additional meaning compared to the typed text. By so doing, I had a variety of data that complement or contrast one another and thus, enriched my understanding about the context and helped me make a solid analysis. The first step that I took was formulating a research question and created preliminary assumption based on common knowledge. The next step was analyzing the dialogues and the performance from selected scenes by implementing Pierre Bourdieu's capital, habitus and field. Further explanation related to the concepts will be explained thoroughly later in the analysis. This step allowed me to identify the causes of domestic violence portrayed in ASoW.

\section{DISCUSSION}

\section{Capital Imbalance in the Marriage}

Domestic violence portrayed in the play occurs because the capitals that each main character has are unequal. Borrowing Bourdieu ideas, capital determines an agent's position in the society. He classifies and categorizes capital into two major groups, social and cultural capital (Bourdieu, 1986). These two capitals are overlapping and influencing each other in ASoW. However, I still want to explain them separately to show how strong Ruben's capitals are compared to Nina's in both aspects.

The first capital is social capital and through these paragraphs it is shown how Ruben's social capital is bigger than Nina's. Social capital is about an agent's relation to other people, or the network/social circle. Therefore, the keyword to understand this capital is by paying attention to "the size of the network of connection that the agent can mobilize, and volume of the capital possessed in his own right by each of those to whom he is connected" (Bourdieu, 1986, p.21). Ruben's and Nina's collective identity is the sign that I read as an indication of each of their position in term of social capital.

Ruben is described as a person who is coming from a family that holds a respected position in their church. This family is well known in the Church community and knows people in that community, like the priest (Monika, 2018, 1.5.). This is when the social capital is also becoming cultural capital. Ruben represents someone who abides to the social norm of being a devout Christian. Even though on Saturday he gets drunk and beats his wife, on Sunday morning, he rises and shines and is ready to go to the church (Monika, $2018,1.4$.). The reason of his devotion is not about being a good Christian but the image of being a good Christian. He needs that image so that his position in his family and community is intact. This is an investment strategy for him to be respected in his family. To seek approval and recognition from his family, especially his father, he uses his obedience as an exchange currency for the recognition from his family. Being a good Christian also brings fame and glory to his name and his family which later can be economic capital to him. It is shown from how one of his reasons to get involve in the church activity and organization is to have a meeting with the priest to renovate the church (Monika, 2018, 1.5.). After Nina experiences the domestic abuse from her husband, her father-in-law instructed Ruben to tell Nina not to go to the church since the bruises can invite questions from the congregation (Monika, 2018, 1.4.). The request from the father-in-law, which is also obeyed by Ruben, indicates how this family values and tries to maintain their reputation in the church. For them church community is also their social capital.

Meanwhile in the same social circle, Nina has nobody in her corner. She has no beneficial social capital since her friends and community are in Bali. The one that she has is actually her mother. However, Ruben's good image in front of Nina's mother, Mrs. Purwa, wins her trust. In fact, due to this image that he represents, Ruben's relation to his mother-in-law is better than his wife's relation to her own mother. He could make Mrs. Purwa believe and Nina hopeful that he is a "sweet lad" who is responsible and a good candidate of a husband as proven by the song Nina sings in Act 1 Scene 2 (Monika, 2018). While Nina's relation to her mother was never smooth, again Nina's perspective is contradictory with her mother's; in her family the one who can understand her is her father who is heavily sick thus cannot be in her corner. It is more often for 
Nina to have a quarrel with her mother. Mrs. Purwa disapproved so many things in Nina's life including the school she took, the job she had, the boyfriend she had. The first scene of Act 1 shows how unhappy Nina is to see her mother even though it has been a few years not to see each other. The cold shoulder that Nina shows is reflected through short sentences and phrases that she uses in the dialog and how fast their conversation escalates into a fight. Nina, at the end of the scene, says "Don't push your luck..." and walks briskly to leave the stage (Monika, 2018, 1.1.). Therefore, in this context, Nina's capital, compare to Ruben's, in relation to Nina's mother, is weaker.

In the Tanadi's house, Nina is a daughter-in-law who cannot meet the expectation of the in-laws. Not only is her mother-in-law belittling Nina's profession as a painter, but she also fails to appreciate Nina's decision to postpone having a child. Nina is seen as someone who cannot obey the values in the community that she is living at the moment. Nina indeed has her social capital, yet, unfortunately, her social capital is not present in this context. Thus, her social capital cannot be her bargaining power to save her a position in the current community.

Ruben is also described as someone who has connection with the police as he is coming from a respected family in the eyes of the authority. When Nina is trying to report the domestic violence that she experienced, the authority is seeing Nina as the enemy of Ruben's family. In Act 2 Scene 3 of the performance, when Nina revealed her objective to report her husband, the policeman who said, "Mr Ruben Tanadi?" delivered the dialog in disbelief intonation and gesture. The policeman also said, "I don't think rape is the right word, Mam... besides, I've known him as a good man, Ma'am" (Monika, 2018, 2.3.). The policeman who is the figure of authority in this context, is facing the victim of a crime. The power relation between these two is not at the same level, yet the one with bigger power fails to sympathize, listen, and understand because he believes (feeling) that it is impossible for a good person to commit such crime; he disregarded the physical evidences (reason) that Nina presented and decided to follow his feeling instead. It is only possible because Ruben's social capital is bigger than Nina.

The second capital, cultural capital, is categorized by Bourdieu (1986) into embodied, objectified, and institutionalized state which can be an asset for an agent to buy position in the society. However, due to the data available, I then focus my analysis to embedded and objectified states only. Embedded state is the quality that an agent has, which "is linked to the body and presupposes embodiment" (Bourdieu, 1986, p. 244). Self-capability and improvement to be able to present the self then become a cultural capital in this sense. The second type of cultural capital is objectified state. It "objectified in material objects and media... can be transmitted as well as economic capital" (Bourdieu, 1986, p. 243). In other words, it has something to do with the possession of the agent (Bourdieu, 1986). I present a table below to show how Ruben surpasses Nina in this category of capital too.

\begin{tabular}{|c|c|c|}
\hline & Ruben & Nina \\
\hline $\begin{array}{l}\text { Embedded } \\
\text { state }\end{array}$ & $\begin{array}{l}\text { Ruben's } \\
\text { communication, } \\
\text { managerial skills help } \\
\text { him become the leader } \\
\text { in Nina's father } \\
\text { company. }\end{array}$ & $\begin{array}{l}\text { Nina's } \\
\text { communication skill } \\
\text { often brings her into } \\
\text { a situation where } \\
\text { she must quarrel } \\
\text { with others to be } \\
\text { understood. }\end{array}$ \\
\hline $\begin{array}{l}\text { Objectified } \\
\text { state }\end{array}$ & $\begin{array}{l}\text { Ruben is living in his } \\
\text { parent's house where } \\
\text { he grew up. He has } \\
\text { more access and sense } \\
\text { of belonging in the } \\
\text { house. }\end{array}$ & $\begin{array}{l}\text { Nina is living in } \\
\text { Ruben's parent } \\
\text { house. The quarrels } \\
\text { she has with her in- } \\
\text { laws, and the } \\
\text { relationship that she } \\
\text { has with her } \\
\text { husband make } \\
\text { things uneasy for } \\
\text { her. Nina only feels } \\
\text { safe in her studio } \\
\text { that is only a room } \\
\text { in the house. }\end{array}$ \\
\hline
\end{tabular}

Based on this table, Ruben's capital is indeed bigger than Nina's. Unfortunately, inequality is inevitable in their relationship which then makes it possible for Ruben to abuse his power over Nina.

Another capital that has not yet been used to analyze the relationship between Ruben and Nina is economic capital. The economic capital is intertwined with social and cultural capitals, and it is not avoidable. According to Bourdieu, economic capital is at the root of all the other types of capital and that these transformed, disguised forms of economic capital, never entirely reducible to that definition, produce their most specific effects only to the extent that they conceal (not least from their possessors) the fact that economic capital is at their root, in other words - but only in the last analysis- at the root of their effects. (Bourdieu, 1986, p. 250)

One of the biggest reasons why Mrs. Purwa, Nina's mother, persuaded Nina to accept Ruben as her husband is because Ruben's role in helping them economically by running their family business (Monika, 2018, 1.1.). This fact is also used by Mrs. Tanadi, Ruben's mother, when Ruben's mother forces 
her idea to urge the couple to have a child as soon as possible and that Nina does not need to work since Ruben can afford everything (Monika, 2018, 1.3.). All capitals at the end intertwined with economic capital. Cultural and social capitals benefit the agent, and in this case, they benefit Ruben more than Nina. Through the analysis, Ruben's cultural and social capitals also bring economic benefit/capital for him. To sum up, based on Bourdieu's concept of capital, indeed inequality happens in the main characters marriage. Nina's capitals are lower than Ruben's and it affects her bargaining position.

\section{The Struggle of Habitus}

The next paragraphs analyze Nina and Ruben's habitus that influence their power relation in their marriage. According to Bourdieu, habitus is "a system of lasting, transposable dispositions which, integrating past experiences, functions at every moment as a matrix of perceptions, appreciations, and actions and makes possible the achievement of infinitely diversified tasks" (quoted in Piroddi, 2021, p.2). It is formed based on the experiences that occur between the individual and his environment.

Comparing Nina and Ruben's relationship with their environment becomes very interesting to understand the schemata that Ruben and Nina have. Nina is described as a girl who is given the freedom, especially by her father, to have an opinion and pursue what she dreams of. Meanwhile, Ruben is described as someone growing up as the first child in an old-fashioned Christian family and obeys whatever his parents tell him to do, the oldest son who becomes the pride of the family (Monika, 2018). These two different parenting styles create different schemata in each character. Nina was educated to know what she wants and knows how to get what she wants. Meanwhile, Ruben depends on what the father's will. The decision she made to marry Ruben was made consciously not for her sake but to save her parents. The habits of the two characters are different in seeing and interpreting their lives. Nina believes that everyone is equal and has their own opinion. Meanwhile, Ruben believes that the opinion which should be heard and obeyed is the one coming from someone who has more powerful position since power is embedded in it.

In the ASOW performance, Ruben's mother repeatedly reminded Ruben of his father's words that he is the head of the family who has the right to govern his wife, and since the dogma is given many times by figures who are more powerful than him, he considers it to be the truth (Monika, 2018, 2.5). Habitus is also changing, seeking a compromise with the existing conditions.
Ruben slowly changes and strengthens his paradigm that the wife must submit to her husband's wishes. Habitus manifests in thinking schemes. This will make a new contribution to build a new principle to bring out a practice in an individual (Rindawati, 2010). In other words, Ruben's habitus in looking at the positions of men and women in the husband-and-wife relation shows that the power relation they have is not balanced. Ruben considers himself more powerful than his wife, and he accepts it as a new necessity and practices it in his daily life. This is the reason for Ruben's abusive action when Nina would not submit to his will. Domestic violence occurs and is not seen as a crime but a necessity: because the husband has the right over his wife, and the wife must obey, so when the wife does not obey, the husband has the right to discipline the wife in the way that the husband chooses.

Ruben's characterization is a result of nurturing process in the family. The nurturing process creates a social order that becomes the value in the family. Based on Bourdieu, social order is reproduced by habitus (Sweetman, 2009). In Tanadi's family, husband is the one who controls the wife. The position of the husband is higher than the wife. It is a value that is being taught and preserved by both Ruben's father and mother. Therefore, Ruben is then pressured by his family to take action toward Nina, to show Nina who is in control, to maintain the social order in the Tanadi's family. This is in line with Bourdieu idea above that social order will be reproduced through habitus.

Ruben's abusive behavior is triggered by the pressure given by her mother who also gets pressure from their social values and her husband. The domestic violence that happened was not only done by Ruben to his wife, as it turned out that Ruben's mother also experienced domestic violence even though it was not physical violence. This can happen because of the same value that they praise, namely that the husband is superior to his wife so that the wife's obedience to her husband is a logical consequence of the husband-and-wife relationship. Based on the explanation above, this imbalanced position causes domestic violence. Meanwhile, this imbalance in position can occur due to the rooted patriarchal ideology that positions men above women. This is what allows violence against women to be considered a logical thing to happen, not a crime.

\section{The Struggling Arena in ASoW}

ASOW presents marriage as a social field which, based on Bourdieu, is a "social structure where the individuals think, act, take position and interact, and then get the legitimation" (Hilgers \& Mangez, 2014, 
p.10). Based on the analysis in the previous sub chapter, Nina and Ruben are struggling in the marriage field where inequality in terms of capitals affects Ruben and Nina's habitus which then become the important factors in positioning these main characters in the field.

In the middle of the play, with her lack of capitals, Nina fails to maintain her equal position in the marriage. She is then trapped in a condition where she thinks becoming a victim of domestic violence is a consequence of being a wife to Ruben. She does not resist, as it shows in Act 2 Scene 1 when Nina says, "They [the wounds and the bruises] have been part of me now..." (Monika, 2018, 2.1.). It is different compared to the first condition of their marriage, when the two have an equal relationship. Structured spaces of dominant and subordinate are positioned based on types and amount of capital (Swartz, 1997). The influence of in-laws and the oppression toward Ruben done by his parents who believe in patriarchy values force them to use their capitals to fight, and since Ruben adopts the patriarchy values, he then uses his power to tame his wife by committing domestic violence.

Ruben receives assurance not only from his family but also from the society who believes that his wife is lucky to marry him and be part of the Tanadi's (Monika, 2018 , 2.1.). The social capital is then becoming a strong weapon to legitimize his position as a husband, and it also protects him from the crime he committed. The field is emphasizing the stratification and domination, so that social arena is a field of production, appropriation, exchange of goods (Swartz, 1997). In the marriage arena, domestic violence is produced due to inequal power between husband and wife as portrayed in ASoW. Ruben's abusive actions are becoming an exchange for Nina's disobedience so that domestic violence is seen as appropriate consequence instead of a crime.

However, "the position of an actor or a group depends not only on the way in which it manages to renew itself but also on the ways in which all the other actors in the field evolve and see to evolve" (Vandenberghe, quoted in Hilgers \& Mathieu, 2014, p. 10). It means Ruben's and Nina's positions can be changed based on the process that each of them has internally and because of external factors; on how the other actors in the field develop gradually and project their development. It gives opportunity to other agents involved in the field to play their role and influence or change each other's position.

As explained above, field is not a fixed concept. The domination and legitimation are fluid; it is a matter of influence or being influenced. The situation in Nina and Ruben's marriage is then influenced by external actors. The agents who also decided to play in Ruben and Nina's marriage field are Galuh, Nina's model, and Markus, Nina's brother-in-law who then influences Nina's mother to change her attitude. Galuh is finally bravely enough to say what she has in mind on the day she will leave Nina, after reminding Nina about her love toward painting and how painting can bring happiness to Nina's life. Galuh also says:

Please don't give up, Gek Nina. Please. I'll do what I can do if you want. (beat) I kept silent the last time.... I kept telling myself to mind my own life. And I regretted it ever since. (beat) You know what happened to her, Gek Nina? To my friend? She died. ... I might be one of those people who get her killed. I could have stopped it, but I didn't. So, please let me help you, Gek Nina. (Monika, 2018, 2.1.)

Galuh's encouragement to remind Nina of what she loves and the capability that she has, empowers Nina to think about another possible way out from her situation. Galuh also shows her support and stand by Nina side. It gives Nina an ally and builds her courage to stand up for herself.

Other supports also come from her mother and her brother-in-law who takes her to make a report at the police station so that a domestic problem happening in private domain turns into an information that can be accessed by the figure of authority. Even though the direct result of this action is not satisfactory since the police sides with Ruben, this event helps Nina exercise her power. In fact, this also helps Markus, who at first did not have his own voice and had to follow his father's order all the time since that is the rule in Tanadi's family (Monika, 2018, 2.3.). Through the reporting event at the police station, he becomes braver and sides with his sister-in-law and starts questioning the abuse (Monika, 2018, 2.3., 2.5.) as well as urging his mother to admit that Ruben is sick and needs some help (Monika, 2018, 2.4.). It also mends the broken relationship between Nina and her mother (Monika, 2018,2.3.). When these supports come, Nina's capitals are stronger, and it changes the power relation between Nina and Ruben. At the end, by having more social capital, Nina is able to gain a stronger position in the marriage field and save herself.

\section{CONCLUSION}

By using concept of capital, habitus, and field from Bordieu, I prove that inequality between the wife and the husband in ASoW is caused by the deeply rooted patriarchy values in society which create imbalance of power between them and create opportunities for domestic violence toward women to happen and place the act more as a logical consequence of the husband- 
and-wife relationship instead of a crime. However, the situation is not permanent. The field, marriage institution, can be influenced by other agents. The agent, who can add capitals, can empower the struggling agent to get more capital to fight the abusive dominant agent. In ASoW case, Nina's mother, Galuh, and Markus later add Nina's social and cultural capitals so that she can remember who she is and her worth. It makes her stronger and then balance the power relation between her and her husband, and fight for her rights. Through ASoW, which is reflecting the Indonesian context, I found that the writer tried to instill and indicate that women and feminist movements can be progressing; that there is a possibility for Indonesian women to fight and to get out from abusive marriage. Women cannot remain silent in the face of inequality, and the bystanders either women or men can support one another other to stop this crime of domestic violence.

Is ASOW then categorized as third wave feminism or power feminism? Whatever name people want to label it, the theater has successfully demonstrated its function as a tool to start discussions about a crime happening in a private domain and raised awareness of the inequal structure of power in an Indonesian marriage preserved by the society which dangerously leads to misconception of the meaning of domestic abuse as domestic consequence instead of a crime. Nina can be a symbol which represents Indonesian women who are moving forward, realizing their strength and potential to get out of their problems, seeing themselves as a survivor, and daring to act to protect themselves instead of simply being a victim. This is better than just a label because the feminist movement must be meaningful instead of just being a label (Gamble, 2001).

To stop domestic violence, both women and men need to re-evaluate the importance and the existence of patriarchal ideology and power relations that are formed. It influences the social order that can harm all members of the field; not only women but also men themselves. The women are obviously in pain, as represented by Nina, and Mrs Tanadi where both are the victims of abusive marriages. Then, as shown by Markus and Ruben, the men are tired and admit their submissiveness to the social structure built around them because they do not think they have another choice. Both parties, men and women, need to selfreflect to see the losses brought by this patriarchal ideology. Pierre Bourdieu states in his book entitled Masculine Domination that domination can only be broken if political decisions are taken by considering all aspects and impacts of domination that occurs not only from the perspective of the masculine order but also the social order (Bourdieu, 2001). These changes will certainly have an impact on the position of men in society; the stronger men and society are guided by patriarchal ideology, the more disadvantages they will experience. The patriarchal ideology has become a threat to all parties because if it continues to be the strongly upheld philosophy, it will lead to a flawed society.

\section{ACKNOWLEDGEMENTS}

I would like to thank Jessie Monika and Petra Little Theatre for writing and producing a play that inspires me to write an article related to a culture that influences and enables domestic violence toward women in Indonesia. I would also like to thank K@TA editorial team who is nothing but supportive in finding the right reviewers for my manuscript. My sincerest gratitude goes to two helpful anonymous reviewers who gave beneficial inputs to sharpen my mind in writing this article.

\section{REFERENCES}

Abigail, E. (2018, December 1). Melawan luka dengan seni [Fighting wounds with the arts]. Jawa Pos. p.4.

Anderson, L. W., Krathwohl, D. R., Airasian, P. W., Cruikshank, K. A., Mayer, R. E., Pinrich, P. R., Raths, J., \& Wittrock, M. C. (Eds.). (2001). A taxonomy for learning, teaching, and assessing. New York: Longman.

Arivia, G. (2006). Feminisme: Sebuah kata hati [Feminism: A word from heart]. Jakarta: Penerbit Buku Kompas.

Arya, A. (2020). An overview of textual analysis as a research method for cultural studies. International Journal for Innovative Research in Multidiciplinary Field, 6(3), pp. 173-177.

Bourdieu, P. (1986). The forms of capital. In J. G. Richardson (Ed.), Handbook of theory and research for the sociology of education (pp. 241258). New York: Greenwood Press.

Bourdieu, P. (2001). Masculine domination. California: Stanford University Press.

Bourdieu, P. (2013). Outline of a theory of practice. Cambridge: Cambridge University Press. (Original work published 1977)

Cohn, N.L. (2020). Feminine identity in ultra-orthodox Jewish women's contemporary art. Shofar: An Interdisciplinary Journal of Jewish Studies, 36(2), pp. 281-301. https://doi.org/10.1353/sho. 2020.0016.

Doblyte, S. (2020). 'Women are tired and men are in pain': Gendered habitus and mental healthcare utilization in Spain. Journal of Gender Studies, 
29(6), pp. 694-705. https://doi.org/10.1080/ 09589236.2020 .1780420

Fitriyani. (2018, January 12). 5 kasus KDRT di Indonesia paling miris, ada yang sampai jual istri [5 horrible domestic violence cases in Indonesia, including selling his wive]. Oke News. https://nasional.okezone.com/read/2018/01/12/3 37/1844191/5-kasus-kdrt-di-indonesia-palingmiris-ada-yang-sampai-jual-istri

Gamble, S. (2001). Postfeminism. In S. Gamble (Ed.), Feminism and postfeminism (pp. 36-45). New york: Routledge.

Hains, R. C. (2009). Power feminism, mediated: Girl power and the commercial politics of change. Women's Studies in Communication, 32(1), 89113. https://doi.org/10.1080/07491409.2009.101 62382

Harker, R., Mahar, C., \& Wilkes, C. (Eds.). (1990). An introduction to the works of Pierre Bourdeau: The Practice of Theory. London: Palgrave Macmillan.

Hilgers, M., \& Mangez, E. (2015). Introduction to Pierre Bourdieu's theory of social fields. In M. Hilgers \& E. Mangez (Eds.), Bourdieu theory of social fields: Concepts and applications (pp. 136). New York: Routledge.

Komnas Perempuan. (2021, March 5). CATAHU 2020 Komnas Perempuan: Lembar fakta dan poin kunci. [Yearly report 2020 Indonesia National Commission on Violence Againts Women: Facts and key points] Laman Komnas Perempuan. https://komnasperempuan.go.id/ siaran-pers-detail/catahu-2020-komnas-perempuan-lembar-fakta-dan-poin-kunci-5-maret2021

Lally, E., Ang, I., dan Anderson, K. (Eds.). (2011). The art of engagement: Culture, collaboration, innovation. Perth: The University of Western Australia Publishing.

McKee, A. (2003). Textual analysis:A beginner's guide. Thousand Oaks, CA: SAGE Publications.

McKenna, J. (2014). Creating community theatre for social change. Studies in Theatre and Performance, 34(1), 84-89. https://doi.org/10.1080/ 14682761.2013 .875721

Monika, J. (2018). A story of wounds. [Unpublished play script].

New Play Development. (2013). Petra Little Theatre. https://petralittletheatre.wixsite.com/petralittlethe atre/new-play-development
Pamungkas, A. (2018, November 15). Ajak masyarakat melawan kekerasan lewat A Story of Wounds. [Inviting people to fight againts violence through A Story of Wounds]. UK Petra. https://fti.petra.ac.id/news/ajak-masyarakatlawan-kekerasan-lewat-a-story-of-wounds

Piroddi, C. (2021). Hope, habitus and social recognition: A Bourdieusian proposal. Journal for the Theory of Social Behavior, 51(4), pp. 619-635. https://doi.org/10.1111/jtsb.12325.

Rindawati. (2010). Habitus dan ranah: Proyek intelektual Pierre Bourdieu membangun teori struktural genetik. [Habitus and domains: Pierre Bourdieu's intellectual project on the structural theory of genetics]. In S. Bagong \& M. K. Amal (Eds.), Anatomi dan perkembangan teori sosial [Anatomy and the development of social theory] (pp. 419-442). Yogyakarta: Aditya Media.

Smith, J. (2017). Textual analysis. In J. Matthes (Ed.), The International Encyclopedia of Communication Reserach Method (pp. 1-7). John Wiley and Sons, Inc. https://doi.org/10.1002/97811189 01731.iecrm0248

Standfield, C. (2020). Gendering the practice turn in diplomacy. European Journal of International Relation, 26(S1), pp.140-165. https://doi.org/10. 1080/09589236.2020.1780420

Sulistyani, H. D. (2012). "Korban dan kuasa" di dalam kajian kekerasan terhadap perempuan ["Victims and power" in the study of violence againts women]. Forum, 39(2), pp. 20-24. https://ejournal. undip.ac.id/index.php/forum/article/view/3153

Swartz, D. (1997). Culture and power: The sociology of Pierre Bourdieu. Chicago: The University of Chicago Press.

Sweetman, P. (2009). Revealing habitus, illuminating practice: Bourdieu, photography and visual methods. The Sociological Review, 57(3), pp. 491-511. https://doi.org/10.1111\%2Fj.1467-954X. 2009.01851.x

Syawitri, M., \& Afdal, A. (2020). Analisis faktorfaktor yang mempengaruhi relasi kuasa pelaku kekerasan dalam rumah tangga (KDRT). [The analysis of factors influencing power relations of the perpetrators' of domestic violence]. JPGI: Jurnal Penelitian Guru Indonesia), 5(1), pp. 3745. https://doi.org/10.29210/02598jpgi0005

Wuriyani, E. P. (2020). Mengenalkan pemikiran Pierre Bourdieu untuk sastra. [Introducing Pierre Bourdieu's thoughts for literature]. Jurnal Edukasi Kultura, 7(1), pp. 1-10. https://doi.org/10.24114/ kultura.vli1.18301 